\title{
Effects of rainfall and slope on runoff, soil erosion and rill development: an experimental study using two loess soils
}

\author{
Haiyan Fang, ${ }^{1}$ Liying Sun ${ }^{1 *}$ and Zhenghong Tang ${ }^{2}$ \\ ${ }^{1}$ Key Laboratory of Water Cycle and Related Land Surface Processes, Institute of Geographic Sciences and Natural Resources Research, Chinese \\ Academy of Sciences, Beijing 100101, China \\ ${ }^{2}$ Community and Regional Planning Program, University of Nebraska-Lincoln, Lincoln, NE 68588-0105, USA
}

\begin{abstract}
:
Runoff generation and soil loss from slopes have been studied for decades, but the relationships among runoff, soil loss and rill development are still not well understood. In this paper, rainfall simulation experiments were conducted in two neighbouring plots (scale: $1 \mathrm{~m}$ by $5 \mathrm{~m}$ ) with four varying slopes $(17.6 \%, 26.8 \%, 36.4 \%$ and $46.6 \%$ ) and two rainfall intensities $(90$ and $120 \mathrm{~mm} \mathrm{~h}^{-1}$ ) using two loess soils. Data on rill development were extracted from the digital elevation models by means of photogrammetry. The effects of rainfall intensity and slope gradient on runoff, soil loss and rill development were different for the two soils. The runoff and soil loss from the Anthrosol surface were generally higher than those from the Calcaric Cambisol surface. Higher rainfall intensity produced less runoff and more sediment for almost each treatment. With increasing slope gradient, the values of cumulative runoff and soil loss peaked, except for the treatments with $90 \mathrm{~mm} \mathrm{~h}^{-1}$ rainfall on the slopes with Anthrosol. With rainfall duration, runoff discharge decreased for Anthrosol and increased for Calcaric Cambisol for almost all the treatments. For both soils, sediment concentration was very high at the onset of rainfall and decreased quickly. Almost all the sediment concentrations increased on the $17.6 \%$ and $26.8 \%$ slopes and peaked on the $36.4 \%$ and $46.6 \%$ slopes. Sediment concentrations were higher on the Anthrosol slopes than on the Calcaric Cambisol slopes. At $90 \mathrm{~mm} \mathrm{~h}^{-1}$ rainfall intensity, increasingly denser rills appeared on the Anthrosol slope as the slope gradient increased, while only steep slopes (36.4\% and 46.6\%) developed rills for the Calcaric Cambisol soil. The contributions of rill erosion ranged from $36 \%$ to $62 \%$ of the cumulative soil losses for Anthrosol, while the maximum contribution of rill erosion to the cumulative soil loss was only $37.9 \%$ for Calcaric Cambisol. Copyright (C) 2014 John Wiley \& Sons, Ltd.
\end{abstract}

KEY WORDS rainfall simulation; slope gradient; runoff; soil erosion; rill; loess soil

Received 1 October 2013; Accepted 2 November 2014

\section{INTRODUCTION}

Bare slopes are very sensitive to runoff and soil loss processes in landscapes. At high intensity rainfall, soil erosion can quickly evolve from splash or sheet erosion to rill or even (ephemeral) gully erosion (Woodward, 1999; Di Stefano et al., 2013). The basic types of erosion include interrill and rill erosion. Rill erosion greatly affects runoff and soil loss on sloping surfaces (Mancilla et al., 2005; Dunkerley, 2008; Auerswald et al., 2009; Wirtz et al., 2012, Shi et al., 2012). Rill erosion can account for up to $90 \%$ of cumulative soil loss (Zheng et al., 1989; Lei et al., 2005; Renard et al., 1997). The evolution from interrill to rill erosion can greatly affect runoff, soil loss and micromorphology as well as the dynamics of the slope surface.

Correspondence to: Liying Sun, Key Laboratory of Water Cycle and Related Land Surface Processes, Institute of Geographic Sciences and Natural Resources Research, Chinese Academy of Sciences, A11 Datun Road, Anwai, Chaoyang District, Beijing 100101, China.

E-mail: sunliying@igsnrr.ac.cn
Slope length and steepness, rainfall intensity, and soil type are among the most important factors influencing runoff generation and soil loss. These factors cause a wide variety of impacts on runoff generation and soil loss. One single factor alone can lead to contradictory results. The infiltration rate has been reported to decrease (e.g. Zaslavsky and Sinai, 1981), increase (Assouline and Ben-Hur, 2006) or remain unchanged with increasing slope gradient (e.g. Fox et al., 1997). Similar to infiltration, contradicting results have been obtained regarding soil loss. Some studies (e.g. Kinnell, 2000; Assouline and Ben-Hur, 2006) reported that soil loss increased with increasing slope gradient, while no correlations were found between soil loss and slope gradient in other studies (Chaplot and Le Bissonnais, 2003). With rainfall duration, peak runoff discharge was reported, resulting from soil sealing (Wainwright, 1996; Fox and Bryan, 1999; Duiker et al., 2001; Gómez and Nearing, 2005; Assouline and Ben-Hur, 2006; Ran et al., 2012). Bryan and Poesen (1989) and Sirjacobs et al. (2000) also found that rills increased water infiltration 
into soil. Rill erosion easily occurs with high intensity rainfall (Brunton and Bryan, 2000), and rill erosion has been found to increase with increasing slope gradient (Berger et al., 2010). However, an inverse result was also observed during a long-duration storm when the dominant factor was overland flow depth and surface storage (Luk et al., 1993). These studies indicate that soil sealing and rill development complicate runoff and erosion characteristics. Most research has focused only on interrill or rill erosion (e.g. Zartl et al., 2001). The responses of runoff and soil loss to slope, rainfall and soil physical property are lesser known when soil erosion processes change from interrill to rill erosion during a rainfall event.

Soil physical property is an intrinsic factor influencing runoff generation and soil loss (Mermut et al., 1997). The most commonly used soil erodibilityK factor is also calculated from soil physical property (Assouline and Ben-Hur, 2006). The susceptibility to soil sealing and rill development is different for different soil properties (Cerdan et al., 2002; Berger et al., 2010). Rill development is also greatly affected by soil erodibility in addition to slope and rainfall characteristics (Bai, 1999; Rejman and Brodowski, 2005; Shao et al., 2005; Neave and Rayburg, 2007; Knapen et al., 2007a). For example, the threshold value of rill occurrence was at $3.5 \%$ to $5.2 \%$ slopes on the loess soils, and at $10.5 \%$ to $21.3 \%$ slopes on the sandy soils (Savat and De Ploey, 1998).

The erosion characteristics in rills are quite different from those in an interrill area (Wirtz et al., 2012), and the transition from interrill to rill erosion is critical both for soil erosion and geomorphic evolution (Brunton and Bryan, 2000). The partitioning of runoff into rill and interrill flows is generally static in current soil erosion models, although the balance between these erosion processes is dynamic and complex because the microtopography is changing over time (Berger et al., 2010). Thus, it is critically important to understand hydrological and sedimentological processes when soil erosion evolves from interrill to rill erosion processes. In current studies, the dynamics of runoff, soil loss and their relation to slope gradient and rainfall intensity are less frequently studied with different soils when erosion forms involve both interrill and rill erosion.

Many studies have been conducted to understand interrill erosion and rill development in the field (e.g. Murphy and Flewin, 1993; Cerdan et al., 2002; Robichaud et al., 2010) and in the laboratory (Brunton and Bryan, 2000; Berger et al., 2010). However, rills are often easy to observe but hard to measure, because of the complexity and stochastic nature of their developing processes. In recent years, digital photogrammetry has been successfully used to exploit this development (e.g. Gómez et al., 2003; Berger et al., 2010). However, the interaction between the microtopographic changes, runoff generation, and soil loss on slopes and their dynamics is lesser known still. The lack of the knowledge could thus impede the disclosure of soil erosion mechanism as well as the soil loss accuracy of model prediction.

Therefore, the objective of this study is to detect the changes in runoff generation and soil loss affected by slope gradient and rainfall characteristics as well as their relation to rill development using conventional methods and close range photogrammetry through rainfall simulation experiments. Differences in runoff generation, soil loss processes and rill development are also investigated using two loess soils.

\section{MATERIALS AND METHODS}

\section{Experimental facilities}

The experiments were conducted with simulated rainfall at the State Key Laboratory of Soil Erosion and Dryland Farming on the Loess Plateau in China.

Because water quality may affect infiltration and soil erosion rates significantly (Kim and Miller, 1996; Jordán et al., 2010), deionized rainfall was employed at intensities of 90 and $120 \mathrm{~mm} \mathrm{~h}^{-1}$ with rainfall duration of 60 and $45 \mathrm{~min}$, respectively. The rainfall intensities were calibrated prior to the experiments. The experiments were conducted in two neighbouring plots (scale: $1 \mathrm{~m}$ by $5 \mathrm{~m}$ ). A metal runoff collector was set at the bottom of each plot to direct the runoff to a container. The plots could be electronically adjusted to the desired slopes. The two soils used in the experiments were collected at 0 to $15 \mathrm{~cm}$ depths from agricultural fields at two sites: one (Anthrosol; FAO/ISRIC/ISSS, 1998) in Yangling and the other (Calcaric Cambisol; FAO/ISRIC/ISSS, 1998) in Ansai on the Chinese Loess Plateau. The soil textures of the two soils are listed in Table I.

\section{Rainfall simulation experiments}

The soil samples were air dried, crushed and passed through a $10.0 \mathrm{~mm}$ sieve. The soil was packed within the plots to achieve its natural bulk density (1.2 to $1.4 \mathrm{~g} \mathrm{~cm}^{-3}$ ). The soil depth within the plot was $30 \mathrm{~cm}$. The filling of the plot was implemented with six soil layers. Each soil layer $(5 \mathrm{~cm}$ depth) was raked lightly to ensure identical soil bulk density for the filled soil. Four slope gradients $(17.6 \%, 26.8 \%, 36.4 \%$ and $46.8 \%)$ were used in the experiments. The $46.8 \%$ slope corresponds with the maximum slope gradient for cultivated land on the Chinese Loess Plateau. Before the rainfall simulations, the soil bulk density and soil water content were tested using the ring method to keep them identical for each experiment. The chosen rainfall intensities of 90 and 
Table I. Soil texture information for Anthrosol and Calcaric Cambisol

\begin{tabular}{|c|c|c|c|c|c|}
\hline & \multicolumn{5}{|c|}{ Soil textures } \\
\hline & $\begin{array}{c}\text { Clay } \\
(<2 \mu \mathrm{m})\end{array}$ & $\begin{array}{l}\text { Fine silt } \\
(2-20 \mu \mathrm{m})\end{array}$ & $\begin{array}{l}\text { Coarse silt } \\
(20-50 \mu \mathrm{m})\end{array}$ & $\begin{array}{c}\text { Fine sand } \\
(50-250 \mu \mathrm{m})\end{array}$ & $\begin{array}{c}\text { Coarse sand } \\
(>250 \mu \mathrm{m})\end{array}$ \\
\hline Anthrosol & 26.06 & 36.55 & 27.92 & 4.25 & 5.22 \\
\hline Calcaric Cambisol & 14.86 & 20.77 & 49.84 & 14.27 & 0.26 \\
\hline
\end{tabular}

$120 \mathrm{~mm} \mathrm{~h}^{-1}$ are typical of intense storms on the Chinese Loess Plateau.

\section{Data collection and treatment}

Runoff and sediment measurements. For each rainfall simulation, the runoff was collected with a $1000 \mathrm{ml}$ graduated flask at 1-min intervals. The collected runoff was deposited to achieve the sediment. The sediment that was separated from the runoff was dried in an oven at $105^{\circ} \mathrm{C}$ until a constant mass was obtained and weighed. The sediment concentration was then calculated as the ratio of the dry sediment mass to the runoff volume. Based on the results of the runoff, time interval and sediment concentration, cumulative runoff, and soil loss data were obtained. During the experiment, the soil surface was artificially monitored to register the time of runoff and rill initiation. A fluorescent dye was used for flow velocity measurement (Shi et al., 2012) at distances of 1, 2, 3 and $4 \mathrm{~m}$ from the slope top once the water flow was stable.

High spatial resolution photography and rill extraction. In order to better detect the rill development, stereophotographs of the flume surface were taken before and after each experiment using ScanStation 2 (by Leica) with a horizontal resolution of $5 \mathrm{~mm}$. This relief surface before rainfall simulation formed the base surface level, named surface 'a'. After rainfall simulation, a second scanning was conducted at the same resolution and, once processed, generated the second digital elevation model (DEM) named surface ' $b$ '. The DEMs were imported into ArcGIS 9.3 software, and the relief difference was obtained using surfaces $a$ and $b$ to estimate rill erosion. The rill length, rill width and rill depth were then extracted using ArcGIS 9.3 software.

Data treatment. Based on the generated DEMs and the extracted rill networks, rill parameters were calculated using the following equations:

$$
R_{\mathrm{d}}=\frac{\sum_{i=1}^{n} L_{i}}{S}
$$

$$
\begin{gathered}
\bar{H}=\frac{\sum_{i=1}^{n} h_{i}}{n} \\
\bar{W}=\frac{\sum_{i=1}^{n} w_{i}}{n} \\
E=\bar{H} \bar{W} R_{\mathrm{d}} \gamma
\end{gathered}
$$

where $R_{\mathrm{d}}$ is the rill density $\left(\mathrm{m} \mathrm{m}^{-2}\right)$, defined as the cumulative rill length per unit area; $L_{i}$ is the $i$ rill length (m); $S$ is the slope surface area $\left(\mathrm{m}^{2}\right) ; H^{-}$is the mean rill depth $(\mathrm{cm}) ; h_{i}$ is the $i$ rill depth $(\mathrm{cm}) ; W^{-}$is the mean width for each rill; $n$ is the number of rills; $E$ is the erosion intensity induced by rills $\left(\mathrm{kg} \mathrm{m}^{-2}\right)$; and $\gamma$ is the dry soil bulk density $\left(\mathrm{g} \mathrm{cm}^{-3}\right)$.

\section{RESULTS}

\section{Runoff}

The cumulative runoff and soil loss after $90 \mathrm{~mm}$ of rainfall on the two soils are shown in Figure 1 as a function of slope gradient for the two rainfall intensities. At $90 \mathrm{~mm} \mathrm{~h}^{-1}$ rainfall, the cumulative runoff changed

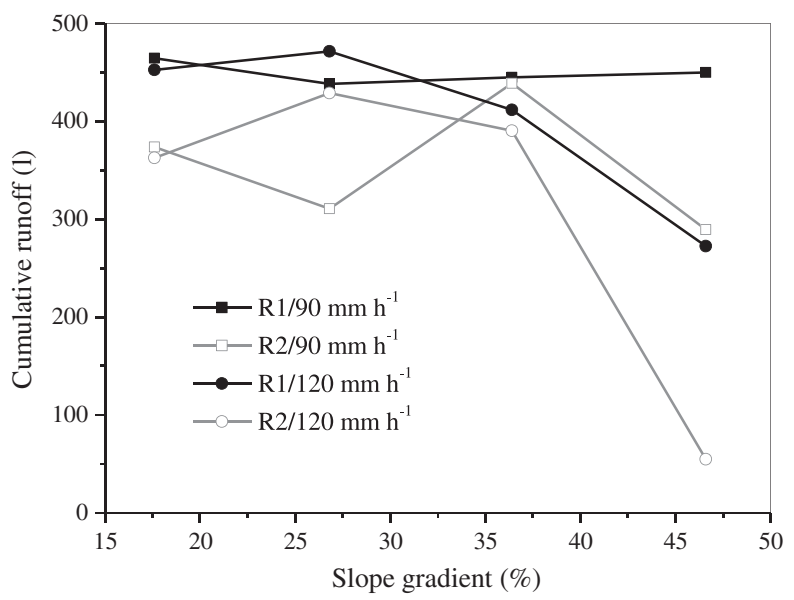

Figure 1. Cumulative runoff from the slopes with different gradients treated with Anthrosol and Calcaric Cambisol at rainfall intensities of 90 and $120 \mathrm{~mm} \mathrm{~h}^{-1}$. R1 and R2 represent runoffs from the slopes with Anthrosol and Calcaric Cambisol, respectively 
little on the Anthrosol soil but fluctuated significantly on the Calcaric Cambisol soil, with a peak value appearing on the $36.4 \%$ slope. At $120 \mathrm{~mm} \mathrm{~h}^{-1}$ rainfall, the cumulative runoff first increased and then decreased, with peak values occurring on the $26.8 \%$ slope for both soils. Comparatively, more cumulative runoff was produced at $90 \mathrm{~mm} \mathrm{~h}^{-1}$ rainfall for both soils except for the $26.8 \%$ slope, and more runoff was generated from the Anthrosol surface than from the Calcaric Cambisol surface with the same treatment.

Figure 2 shows the dynamics of runoff discharge on the two soils during the rainfall event for the different rainfall intensities and slope gradients. At both rainfall intensities, runoff discharge from Anthrosol decreased with rainfall duration on the mild $(17.6 \%$ and $26.8 \%)$ slopes and presented convex patterns on the steep $(36.4 \%$ and $46.6 \%)$ slopes. In comparison, runoff discharge from the Calcaric Cambisol soil increased except for the soil on the $36.6 \%$ slope. For each treatment, runoff discharge sharply decreased at the end of the rainfall event. More runoff was generated from the Anthrosol soil than from the Calcaric Cambisol soil at any given time for the same treatment, except for those at $120 \mathrm{~mm} \mathrm{~h}^{-1}$ rainfall on $17.6 \%$ and $36.4 \%$ slopes. Higher rainfall intensity yielded a higher runoff discharge at almost every specific time interval for the same treatment. With increasing slope gradients, runoff discharge fluctuated greatly at $120 \mathrm{~mm} \mathrm{~h}^{-1}$ rainfall for both soils.
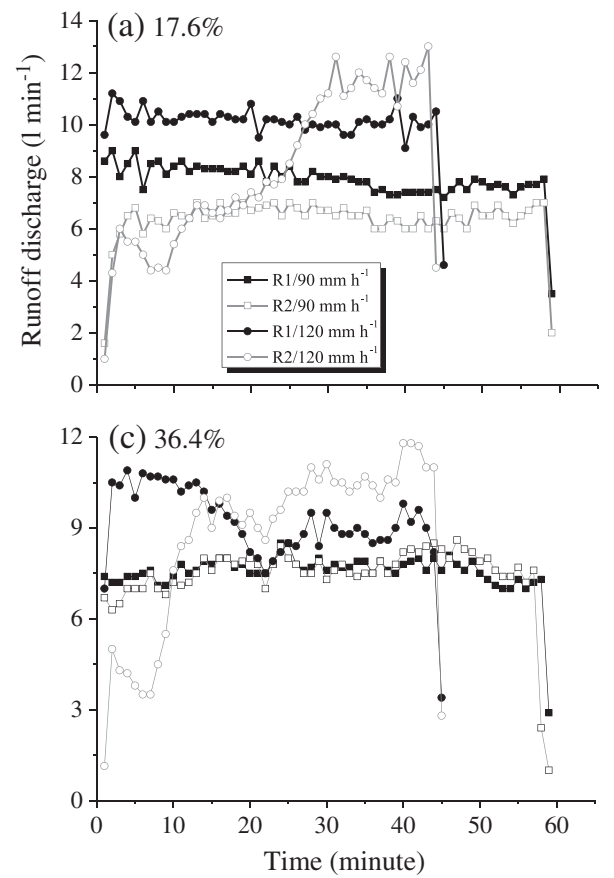
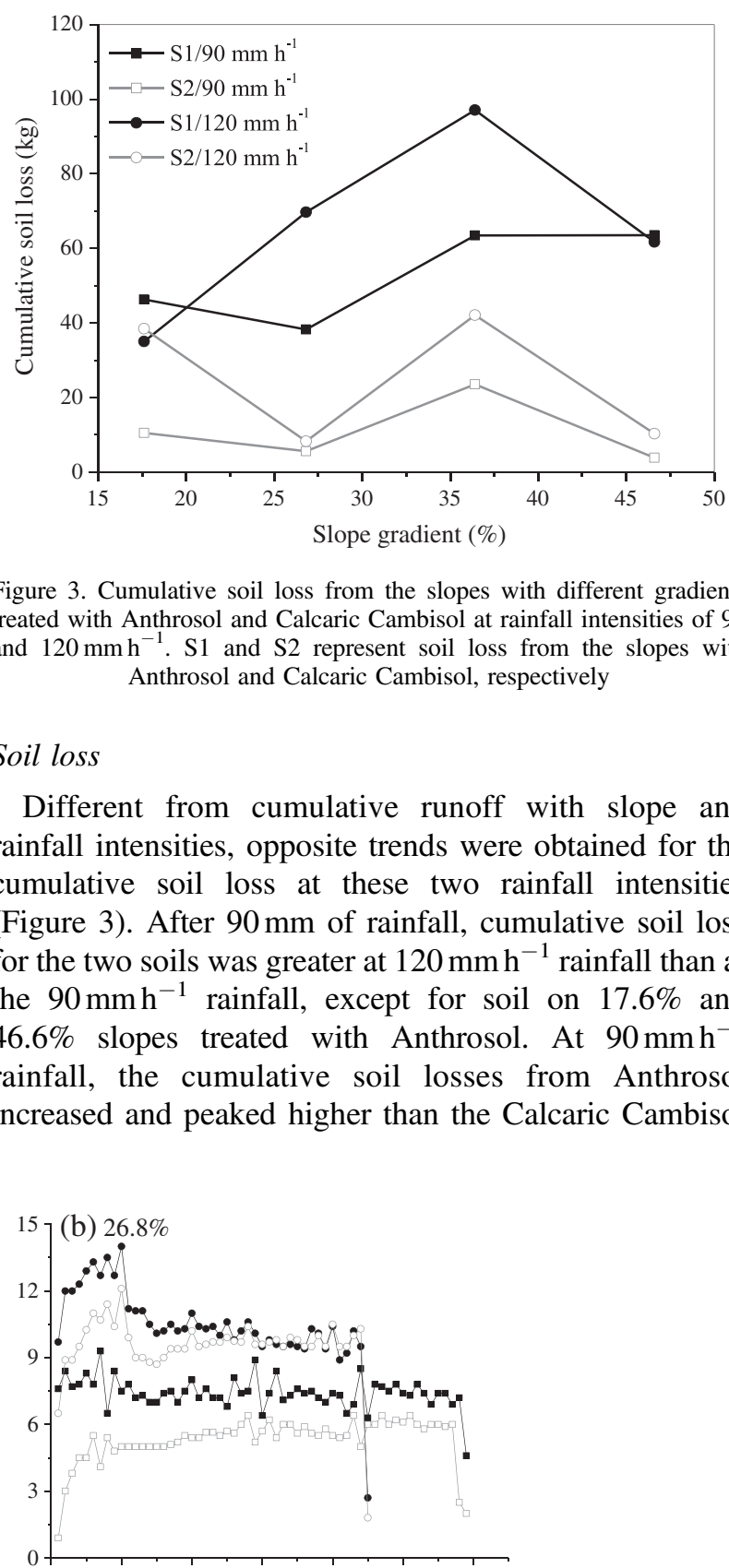

Figure 3. Cumulative soil loss from the slopes with different gradients treated with Anthrosol and Calcaric Cambisol at rainfall intensities of 90 and $120 \mathrm{~mm} \mathrm{~h}^{-1}$. S1 and S2 represent soil loss from the slopes with Anthrosol and Calcaric Cambisol, respectively

\section{Soil loss}

Different from cumulative runoff with slope and rainfall intensities, opposite trends were obtained for the cumulative soil loss at these two rainfall intensities (Figure 3). After $90 \mathrm{~mm}$ of rainfall, cumulative soil loss for the two soils was greater at $120 \mathrm{~mm} \mathrm{~h}^{-1}$ rainfall than at the $90 \mathrm{~mm} \mathrm{~h}^{-1}$ rainfall, except for soil on $17.6 \%$ and $46.6 \%$ slopes treated with Anthrosol. At $90 \mathrm{~mm} \mathrm{~h}^{-1}$ rainfall, the cumulative soil losses from Anthrosol increased and peaked higher than the Calcaric Cambisol

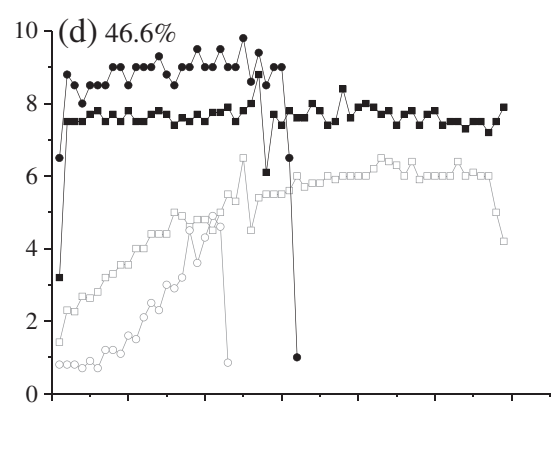

Figure 2. Dynamics of runoff discharge at two rainfall intensities and two soils on the slopes of (a) $17.6 \%$, (b) $26.8 \%$, (c) $36.4 \%$ and (d) $46.6 \%$ during the rainfall events. R1 and R2 represent runoffs from the slopes with Anthrosol and Calcaric Cambisol, respectively 

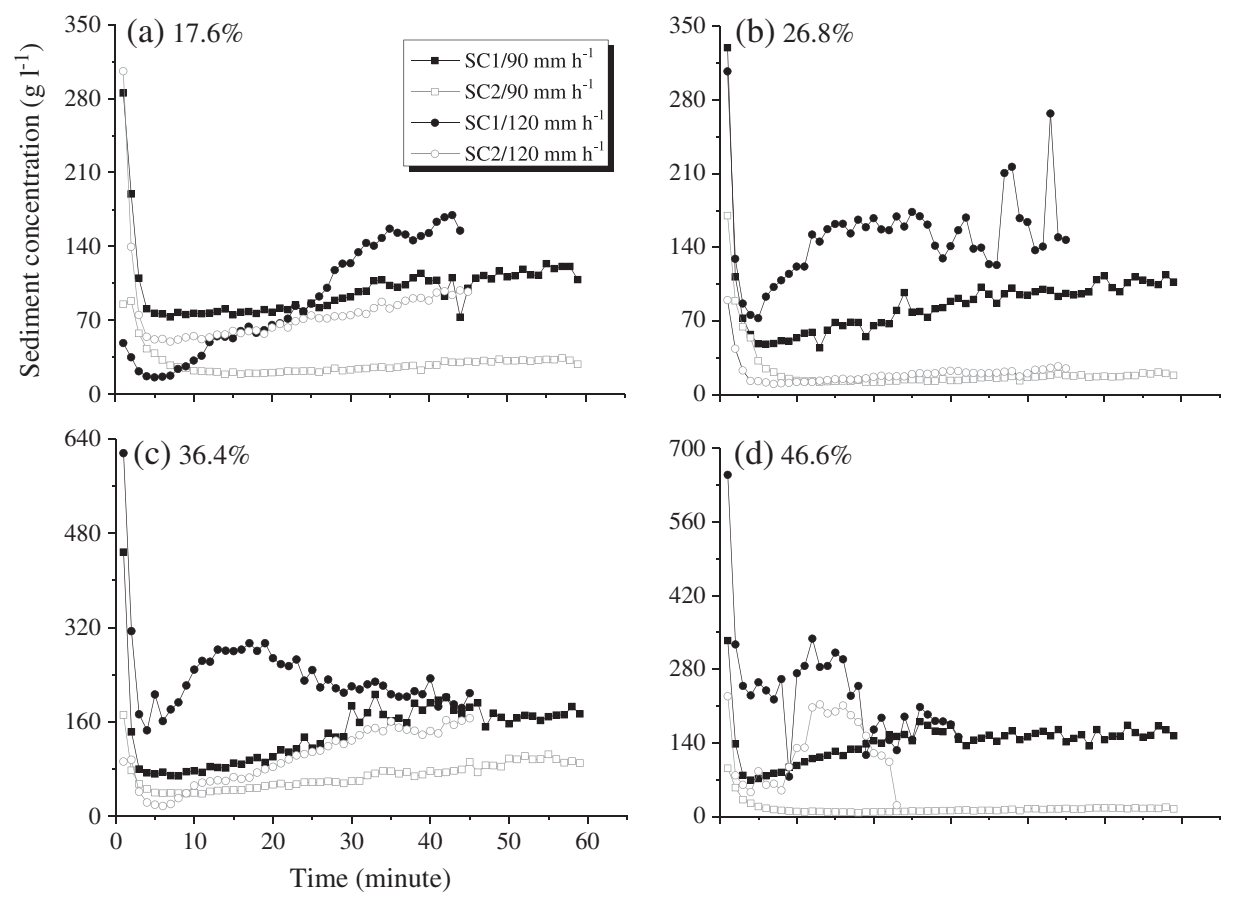

Figure 4. Dynamics of sediment concentration at two rainfall intensities and two soils on the slopes of (a) $17.6 \%$, (b) $26.8 \%$, (c) $36.4 \%$ and (d) $46.6 \%$ during the rainfall events. SC1 and SC1 represent sediment concentrations from the slopes with Anthrosol and Calcaric Cambisol, respectively

on the $36.4 \%$ slope. The cumulative soil losses from both soils at $120 \mathrm{~mm} \mathrm{~h}^{-1}$ rainfall had peak values on the $36.4 \%$ slope. Similar to the cumulative runoff, the cumulative soil losses from Anthrosol were more than from Calcaric Cambisol for each treatment, with the exception of the treatment on the $17.6 \%$ slope at $120 \mathrm{~mm} \mathrm{~h}^{-1}$ rainfall because of more and deeper headcuts occurring on the soil surface.

The sediment concentration had almost the same dynamic pattern as rainfall duration with both soils (Figure 4). The sediment concentrations were very high at the onset of the rainfall and decreased sharply with rainfall continuing through its duration. In the latter stages of the rainfall simulation, the sediment concentrations increased or remained constant for almost all the treatments. Noticeably, sediment concentrations presented convex trends on $36.4 \%$ and $46.6 \%$ slopes at $120 \mathrm{~mm} \mathrm{~h}^{-1}$ rainfall. In contrast, the sediment concentration from Anthrosol was higher than that from Calcaric Cambisol at almost any given time for the same treatment except for the $17.6 \%$ slope because of more collapsed soil blocks from the headcuts.

\section{Rill development}

Figure 5 shows the developed rills with increasing slope gradient at $90 \mathrm{~mm} \mathrm{~h}^{-1}$ rainfall for the two soils. Anthrosol treatments developed an intensively rilled surface. The rill networks became denser with an increasing slope gradient except for the $26.8 \%$ slope.
No rills developed on the Calcaric Cambisol surface for the $17.6 \%$ and $26.8 \%$ slopes, and only sparse rills occurred on the $36.4 \%$ and $46.6 \%$ slopes. Table II quantifies rill observations at $90 \mathrm{~mm} \mathrm{~h}^{-1}$ rainfall. The rill density $R_{\mathrm{d}}$ increased with increasing slope gradient for both soils, and higher rill densities appeared on the Anthrosol slopes, ranging from 3.29 to $6.89 \mathrm{~m} \mathrm{~m}^{-2}$. The ratio of rill width to rill depth $(W / H)$ decreased with increasing slope gradient for both soils. The rill $W / H$ value on the Calcaric Cambisol surface was larger than that on the Anthrosol surface. The contribution of rill erosion to the cumulative soil loss increased with increasing slope gradient, with the largest values of $61.29 \%$ and $37.88 \%$ on the $46.6 \%$ slope with Anthrosol and Calcaric Cambisol, respectively.

\section{DISCUSSION}

The complex patterns of runoff, soil loss and rill development on the slopes reflect the dynamics of interrill and rill erosions as affected by soil texture, slope gradient and rainfall intensity. Interrill erosion is dominated by raindrop impact, usually leading to soil crusting. The compacted soil layer decreases the permeability of the soil and increases runoff generation (Al-Qinna and Awwad, 1998; Carmi and Berliner, 2008). When the shear stress of runoff is larger than soil resistance (Loch, 1996; Gover et al., 2007; Knapen 


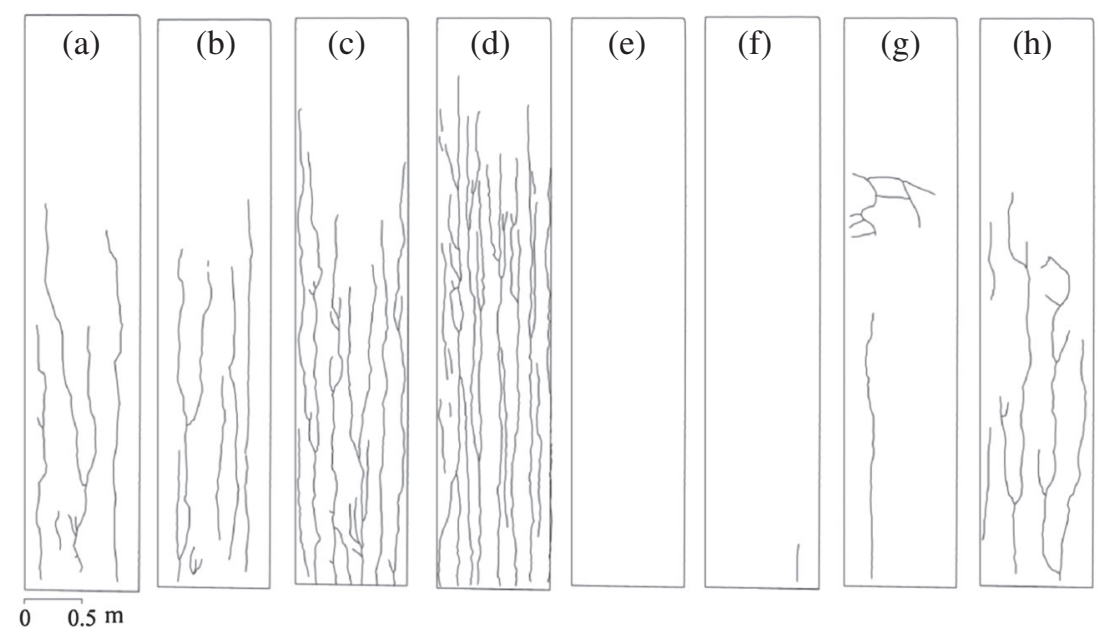

Figure 5. Rill networks developed at $90 \mathrm{~mm} \mathrm{~h}^{-1}$ rainfall for the two soils: on the Anthrosol soil surface with slope gradients of (a) $17.6 \%$, (b) $26.8 \%$, (c) $36.4 \%$ and (d) $46.6 \%$, and on the Calcaric Cambisol soil surface with slope gradients (e) $17.6 \%$, (f) $26.8 \%$, (g) $36.4 \%$ and (h) $46.6 \%$

Table II. Characteristics of rills' development at $90 \mathrm{~mm} \mathrm{~h}^{-1}$ rainfall for the two soils

\begin{tabular}{lccccccc}
\hline & Slope $(\%)$ & $R_{\mathrm{d}}\left(\mathrm{m} \mathrm{m}^{-2}\right)$ & $\bar{H}(\mathrm{~cm})$ & $\bar{W}(\mathrm{~cm})$ & $W / H$ & $E(\mathrm{~kg})$ & Ratio $(\%)$ \\
\hline Anthrosol & 17.6 & 3.55 & 3.9 & 2.4 & 0.62 & 17.63 & 38.06 \\
& 26.8 & 3.29 & 4.3 & 2.5 & 0.58 & 17.61 & 36.51 \\
& 36.4 & 4.89 & 6.1 & 1.9 & 0.31 & 30.49 & 48.06 \\
Calcaric & 46.6 & 6.89 & 6.4 & 1.6 & 0.25 & 38.92 & 61.29 \\
Cambisol & 17.6 & 0 & 0 & 0 & 0 & 0 & 0 \\
& 26.8 & 0.01 & 0.84 & 0.70 & 0.83 & 0.01 & 0 \\
& 36.4 & 0.41 & 2.22 & 2.15 & 0.97 & 1.04 & 4.41 \\
& 46.6 & 1.06 & 3.46 & 1.09 & 0.32 & 2.12 & 37.88 \\
\hline
\end{tabular}

et al., 2007b; Shi et al., 2012), a rill develops (Léonard et al., 2006), which leads to a higher water infiltration rate and more soil loss (Poesen,1984; Fox et al., 1997; Shi et al., 2013).

Studies have found that soils with high silt content and $20 \%$ to $30 \%$ clay were the most susceptible to crusting (Ben-Hur et al., 1985; Mermut et al., 1995, 1997; Fang et al., 2008a). According to this finding, Anthrosols would experience faster soil crusting compared with Calcaric Cambisols (Table I). This inference has been verified by Cheng (2008), who found that a better developed crusting layer occurred on an Anthrosol surface, although it experienced a shorter rainfall duration (Figure 6). In addition, the Calcaric Cambisol had a higher sand content of $14.53 \%$. The filling of voids among the coarse particle and clay illuviation requires more time to develop a crust (Bajracharya and Lal, 1999), and more runoff is infiltrated into the Calcaric Cambisol surface. This can explain the higher cumulative runoffs from the Anthrosol surface than from Calcaric Cambisol surface (Figures 1 and 2). On mild slopes (17.6\% and $26.8 \%$ ), the runoff tractive force was smaller and no rills developed on the Calcaric Cambisol surface. In contrast, a higher runoff tractive force on the Anthrosol surface resulted in denser rill networks (Figure 5) and greater soil loss (Figure 4; Singer and Bissonnais, 1998; Singer and Shainberg, 2004). The difference in the development of crust and rills for the two soils could explain the dynamic changes in runoff discharge. On the mild slopes (17.6\% and $26.8 \%$ ) with the Anthrosol, although a crust can be easily formed, the increase in runoff by crusting could not offset the reduction of runoff by rill infiltration, resulting in decreasing runoff discharge with rainfall duration (Figure 2). At the same time, runoff discharge from the Calcaric Cambisol surface increased because of a longer soil crusting period (Figure 4). The convex patterns of runoff discharge on $36.4 \%$ and $46.6 \%$ slopes can be explained by the interactions of crusting and rill development. During a rainfall event, crust dominated the former stage and increased runoff discharge. However, rill development in the latter stage resulted in a lower runoff discharge (Figure 2). As rain continued to fall, more water was infiltrated into the soil and the coarsetextured Calcaric Cambisol soil collapsed easily on the steep slopes $(36.4 \%$ and $46.6 \%$ ), resulting in larger $W / H$ values of rills and greater fluctuation of sediment concentration (Table II; Figure 4). Noticeably, the sharp drop of runoff discharge at the end of the rainfall event 

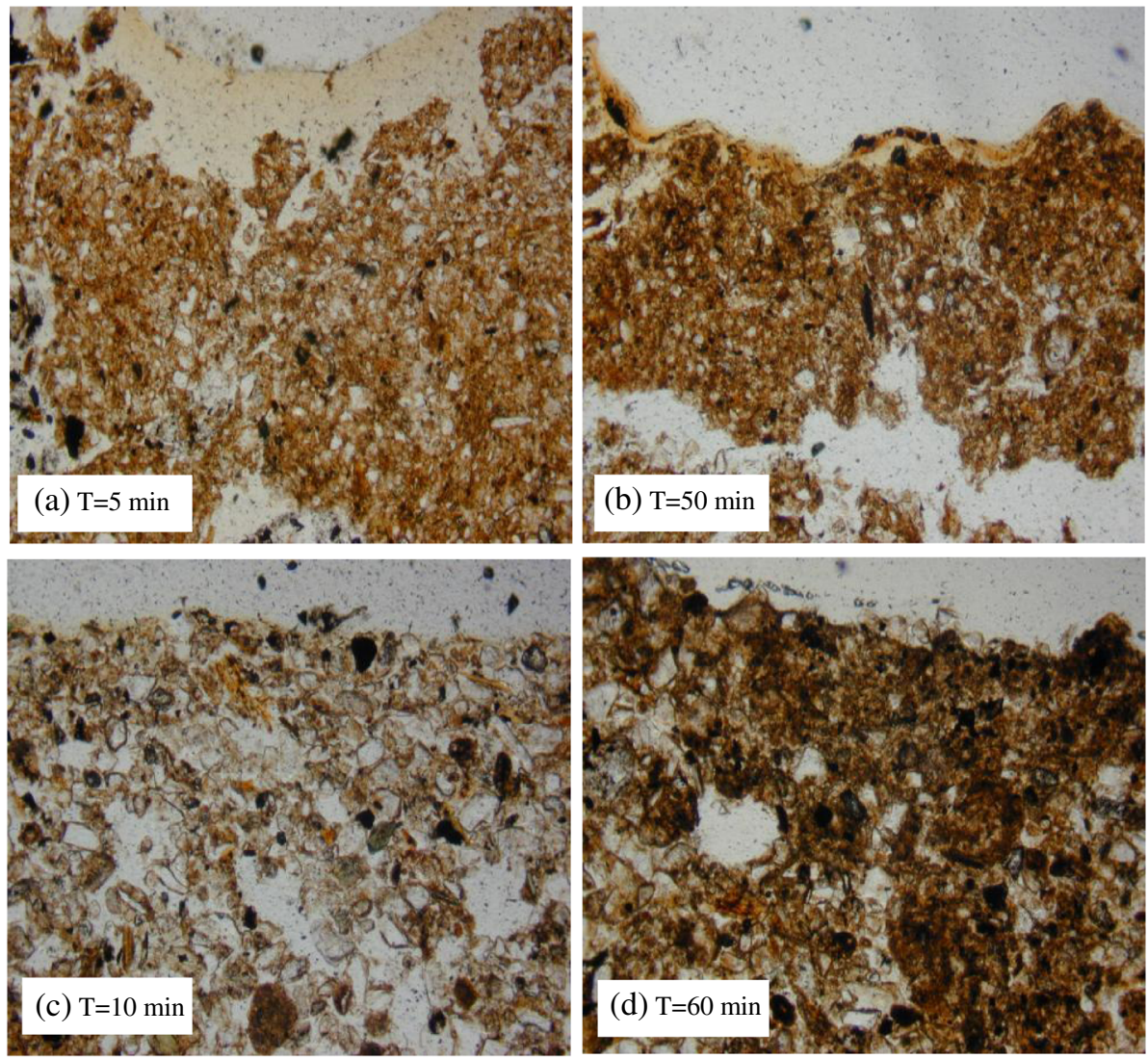

Figure 6. Vertical profiles of the soil crust (at 40× magnification) formed on the Anthrosol surface subjected to 5 (a) and 50 min (b) and on the Calcaric Cambisol surface subjected to 10 (c) and $60 \mathrm{~min}$ (d). The simulated rainfall was $72 \mathrm{~mm} \mathrm{~h}^{-1}$. The fuscous part is soil particle. The micrographs are cited from Cheng (2008)

could be a result of a higher infiltration rate and a sudden halt to the rainfall.

The transition from an interrill to rill erosion process is also critical for soil loss (Kinnell, 2000; Shi et al., 2012). The higher sediment concentrations at the beginning of a rainfall could reflect the transport-limited sediment regime (Kinnell, 2005). With continuing rainfall, this sediment regime changed and sediment concentration decreased. Later, the developing rills increased the sediment concentration for the slopes with Anthrosol soil. For Calcaric Cambisol soil at $90 \mathrm{~mm} \mathrm{~h}^{-1}$ rainfall, the poorly developed rills resulted in a small increase in sediment concentration on the mild slopes $(17.6 \%$ and $26.8 \%$ ). The sharp increase in sediment concentration on the $36.4 \%$ slope at $90 \mathrm{~mm} \mathrm{~h}^{-1}$ rainfall was probably caused by the collapse of the rills. At $120 \mathrm{~mm} \mathrm{~h}^{-1}$ rainfall, the more intense changes in sediment concentration were probably a result of a more rapid crust-rill evolution process, characterized by the earlier occurrence of droppit (Table III). The convex patterns of sediment concentration with continuing rainfall probably resulted from the interaction of crusting and rills. Crust can also be formed during its disruption process (Cheng, 2008). The development of rills in an interrill area increased sediment concentration, while the redeveloped crust decreased sediment concentration again (Figure 4). Furthermore, the convex of sediment concentration could probably be the larger tractive force of runoff discharge, because convex changes in runoff discharge also took place (Figure 2).

Different conclusions regarding the effects of slope gradient on runoff generation and soil loss have been reported (Fox et al., 1997). In our experiment, an increase in slope gradient enhanced water flow velocity (Table III) and reduced the chance that runoff would be infiltrated into the soils. However, the developing rills can also increase infiltration into soils. The interactions made the cumulative runoff from Anthrosol almost constant with increasing gradient at $90 \mathrm{~mm} \mathrm{~h}^{-1}$ rainfall. The threshold values of runoff at $120 \mathrm{~mm} \mathrm{~h}^{-1}$ rainfall for the two soils (Figure 1) can be explained by at least three factors: (1) cumulative rainfall on the slopes, (2) the soil crusting and its duration, and (3) the rill development. With increasing slope gradient, the projected area of the slope surface decreased more and more sharply, resulting in less rain falling and less runoff yield from the soils (Figure 1a). The variations in cumulative runoff could also be reflected by the developing soil crust and rills (Bryan and Poesen, 1989). On the mild slopes (17.6\% and 26.8\%), soil crust formed 
Table III. Comparison of the runoff characteristics and drop-pit initiation during experiments for the two soils

\begin{tabular}{|c|c|c|c|c|c|c|c|}
\hline \multirow{2}{*}{$\begin{array}{l}\text { Rainfall } \\
\text { intensity } \\
\left(\mathrm{mm} \mathrm{h}^{-1}\right)\end{array}$} & \multirow{2}{*}{$\begin{array}{c}\text { Slope } \\
(\%)\end{array}$} & \multicolumn{2}{|c|}{ Time to incipient runoff (min) } & \multicolumn{2}{|c|}{ Time to incipient drop-pit (min) } & \multicolumn{2}{|c|}{ Mean runoff velocity $\left(\mathrm{m} \mathrm{s}^{-1}\right)$} \\
\hline & & Anthrosol & Calcaric Cambisol & Anthrosol & Calcaric Cambisol & Anthrosol & Calcaric Cambisol \\
\hline \multirow[t]{4}{*}{90} & 17.6 & 1.80 & 2.47 & 14 & - & 0.21 & 0.24 \\
\hline & 26.8 & 1.87 & 3.45 & 7 & 15 & 0.18 & 0.32 \\
\hline & 36.4 & 1.85 & 1.67 & 11 & 12 & 0.24 & 0.30 \\
\hline & 46.6 & 1.42 & 3.32 & 6 & 7 & 0.27 & 0.32 \\
\hline \multirow[t]{4}{*}{120} & 17.6 & 1.03 & 1.83 & 9 & 8 & 0.21 & 0.25 \\
\hline & 26.8 & 1.13 & 1.28 & 7 & 15 & 0.24 & 0.30 \\
\hline & 36.4 & 1.40 & 1.60 & 7 & 14 & 0.22 & 0.27 \\
\hline & 46.6 & 1.22 & 1.83 & 6 & 6 & 0.20 & 0.15 \\
\hline
\end{tabular}

indicates no drop-pit occurrence.

rapidly, which increased cumulative runoff. With rainfall duration, although the partial crust was destroyed, the mild slopes with undeveloped rill networks could still produce more cumulative runoff. On steep slopes $(36.4 \%$ and $46.6 \%$ ), less tractive force is required to destroy the crusting soil (Figure 3; Poesen, 1984; Fox et al., 1997), resulting in less cumulative runoff. The opposing effects of surface crust and rill infiltration on runoff discharge were also found by Gabriels (1999). The interactions of rainfall amount, crusting and rills on different slopes led to the peak values of cumulative runoff.

Similar to the threshold values of cumulative runoff, the threshold values of cumulative soil loss on the $36.4 \%$ slope for the two soils could be explained by the interaction of runoff generation and sediment concentration. On the mild slope $(17.6 \%$ and $26.8 \%$ ), crust dominated with lower sediment concentration and runoff (Figures 1 and 2). With increasing slope gradient, rill networks became denser, which increased sediment concentrations (Figure 4). The contributions of rill erosion to the cumulative soil loss ranging from $38.06 \%$ to $61.29 \%$ for the Anthrosol surface were comparable with the estimates by Loch and Donnollan (1983) and Freebairn and Wockner (1986). However, well-developed rills decreased the cumulative runoff. Thus, the interactions of cumulative runoff and sediment concentration yielded the threshold values of cumulative soil loss (Figure 3). The threshold values of soil loss with increasing slope gradient were often found in other studies. For example, the threshold values occurred on slopes ranging from $44.5 \%$ to $119.2 \%$ in gradient for the Chinese Loess Plateau (Cao, 1993; Jin, 1995; Liu et al., 2001; Chen et al., 2010). Noticeably, because of lower rainfall intensity, the cumulative soil losses from Anthrosols increased with increasing slope gradient, and no threshold value of cumulative soil loss was observed at $90 \mathrm{~mm} \mathrm{~h}^{-1}$ rainfall.

Rainfall intensity is the extrinsic energy influencing runoff generation and soil loss (Fang et al., 2008b). High intensity rainfall greatly disturbs thin water flow on the slopes and can easily breach the crusted soil surface. Table III shows that the time to the incipient drop-pit was shorter at $120 \mathrm{~mm} \mathrm{~h}^{-1}$ rainfall. This means that the rill network developed better at a higher rainfall intensity, resulting in a higher infiltration rate and lower cumulative runoff for the same treatment (Figure 1). However, because of higher sediment concentration at higher rainfall intensity, $120 \mathrm{~mm} \mathrm{~h}^{-1}$ rainfall produced more cumulative soil than that at $90 \mathrm{~mm} \mathrm{~h}^{-1}$ on $26.8 \%$ and $36.4 \%$ slopes. Compared with that at $90 \mathrm{~mm} \mathrm{~h}^{-1}$, the lower cumulative soil loss at $120 \mathrm{~mm} \mathrm{~h}^{-1}$ rainfall from the $46.6 \%$ slope resulted from less experimental time (Figure 2). Soil crust developed well on the $17.6 \%$ slope at the former $20 \mathrm{~min}$, and the sediment concentration was less than $500 \mathrm{gl}^{-1}$. This could explain the smaller cumulative soil loss at $120 \mathrm{~mm} \mathrm{~h}^{-1}$ compared with that at $90 \mathrm{~mm} \mathrm{~h}^{-1}$.

Runoff and sediment yields are not a simple function of rainfall intensity, slope gradient and soil type. They are directly influenced by soil crust and rill development. The crust increases runoff discharge and protects the soil from erosion (Bryan and Poesen, 1989; Mermut et al., 1995; Carmi and Berliner, 2008; Shi et al., 2010), but subsequent rill incision could breach the crusting soil and significantly affect runoff and soil loss. The interactions of rainfall intensity, slope gradient and soil texture made the relationship of runoff, soil loss and rill development more complex.

\section{CONCLUSIONS}

In our present study, the effects of slope gradient, rainfall and soil on runoff, soil loss and rill development were studied through an experiment using conventional methods and close range photogrammetry, and some meaningful conclusions were reached.

Soil physical property greatly influences soil sealing and rill development. The lower infiltrated Anthrosol had a faster crust-rill evolution process and a well-developed 
rill network, which induced higher runoff and soil loss than Calcaric Cambisol for the same slope and rainfall combination. The cumulative runoff and soil loss changed with varying rainfall intensity and slope gradient. Impacted by the interactions of interrill and rill erosion, low intensity rainfall produced more runoff but less soil loss for both soils. With increasing slope gradient, cumulative runoff from Anthrosol presented a decreasing trend, while peak values appeared on the slope with Calcaric Cambisol. Different from cumulative runoff, cumulative soil loss had a threshold value with increasing slope gradient, with a peak value appearing on the $36.4 \%$ slope for both soils.

The development of soil crust and rill, as well as their dynamic evolution, directly determines the dynamics of runoff and sediment concentration with rainfall duration. A steeper slope, higher rainfall intensity and low-infiltrated Anthrosol induced a faster evolution from crust to rill. For individual treatment, almost all the runoff discharges from Anthrosol presented a decreased trend and an increased trend from Calcaric Cambisol. The developed rills produced a higher sediment concentration with Anthrosol than with Calcaric Cambisol almost at any given time. The sediment concentrations increased with rainfall duration for both soils for almost every run, resulting from the evolution from soil crust to rill. Excluding the initial time of each run, sediment concentration increased with time at $17.6 \%$ and $26.8 \%$ slopes while presenting a convex pattern on $36.4 \%$ and $46.6 \%$ slopes with rainfall duration.

The interactions among soil physical property, slope condition and rainfall intensity directly impact interrill and rill erosions that make runoff and soil loss complex and unable to be described with a simple equation. Our research of the complex interactions among the factors would greatly deepen the mechanism study of soil erosion on slopes. Furthermore, consideration of the dynamic development of crust and rill on the slope for the soil erosion model would also greatly increase the accuracy of model prediction.

\section{ACKNOWLEDGEMENTS}

This work is financially supported by the projects of the Open Fund of Key Laboratory of Ministry of Water Resource of Soil and Water Loss Processes and Control on the Loess Plateau (grant number 201204), the National Natural Science Foundation of China (grant number $41271305,41271304)$. Thanks are also given to the State Key Laboratory of Soil Erosion and Dryland Farming on the Loess Plateau in China that provided the location to do this experiment. The authors are grateful to two anonymous reviewers for their constructive comments that improved this paper.

\section{REFERENCES}

Al-Qinna MIA, Awwad AMA. 1998. Infiltration rate measurements in arid soils with surface crust. Irrigation Science 18: 83-89.

Assouline S, Ben-Hur M. 2006. Effects of rainfall intensity and slope gradient on the dynamics of interrill erosion during soil surface sealing. Catena 66: 211-220.

Auerswald K, Fiener P, Dikau R. 2009. Rates of sheet and rill erosion in Germany - a meta-analysis. Geomorphology 111: 182-193.

Bai QJ. 1999. Study on the runoff and sediment yields in the rill-erosion zone on the slope of the Loess Plateau. Northwest Agriculture and Forestry University, Xi'an, China (Ph.D. Dissertation).

Bajracharya RM, Lal R. 1999. Land use effects on soil crusting and hydraulic response of surface crusts on a tropical Alfisol. Hydrological Processes 13: 59-72.

Ben-Hur M, Shainberg I, Bakker D, Keren R. 1985. Effect of soil texture and $\mathrm{CaCO}_{3}$ content on water infiltration in crusted soil. Irrigation Science 6: 281-294.

Berger C, Schulze M, Rieke-Zapp D, Schlunegger F. 2010. Rill development and soil erosion: a laboratory study of slope and rainfall intensity. Earth Surface Processes and Landforms 35: 1456-1467.

Brunton DA, Bryan RB. 2000. Rill network development and sediment budgets. Earth Surface Processes and Landforms 25: 783-800.

Bryan RB, Poesen J. 1989. Laboratory experiments on the influence of slope length on runoff, percolation and rill development. Earth Surfaces Process and Landforms 14: 211-231.

Cao WH. 1993. Slope thresholds of soil erosion. Bulletin of Soil and Water Conservation 13: 1-5.

Carmi G, Berliner P. 2008. The effect of soil crust on the generation of runoff on small plots in an arid environment. Catena 74: 37-42.

Cerdan O, Le Bissonnais Y, Couturier A, Bourennane H, Souchère V. 2002. Rill erosion on cultivated hillslopes during two extreme rainfall events in Normandy, France. Soil and Tillage Research 67: 99-108.

Chaplot VAM, Le Bissonnais Y. 2003. Runoff features for interrill erosion at different rainfall intensities, slope lengths, and gradients in an agricultural loessial hillslope. Soil Science Society of American Journal 67: 844-851.

Chen XA, Cai QG, Zhang LC, Qi JY, Zheng MG, Nie BB. 2010. Research on critical slope of soil erosion in a hilly loess region on the Loess Plateau. Journal of Mountain Science 28: 415-421.

Cheng QJ. 2008. Erosion responses and factors affecting soil crust in typical soil and water loss regions, China. Graduate University of Chinese Academy of Sciences, Beijing, China (Ph.D. Dissertation).

Di Stefano C, Ferro V, Pampalone V, Sanzone F. 2013. Field investigation of rill and ephemeral gully erosion in the Sparacia experimental area, South Italy. Catena 101: 226-234.

Duiker SW, Flanagan DC, Lal R. 2001Erodibility and infiltration characteristics of five major soils of southwest Spain. Catena 45: 103-121.

Dunkerley D. 2008. Rain event properties in nature and in rainfall simulation experiments: a comparative review with recommendations for increasingly systematic study and reporting. Hydrological Processes 22: 4415-4435.

Fang HY, Cai QG, Chen H, Li QY. 2008a. Effect of rainfall regime and slope on runoff in a gullied Loess Region on the Loess Plateau in China. Environmental Management 42: 402-411.

Fang HY, Cai QG, Chen H, Li QY. 2008b. Temporal changes in suspended sediment transport in a gullied loess basin: the lower Chabagou Creek on the Loess Plateau in China. Earth Surface Processes and Landform 33: 1977-1992.

FAO/ISRIC/ISSS. 1998. World reference base for soil resources. World Soil Resources Reports, Rome.

Fox DM, Bryan RB, Price AG. 1997. The influence of slope angle on final infiltration rate for interrill conditions. Geoderma 80: 181-194.

Fox DM, Bryan RB. 1999. The relationship of soil loss by interrill erosion to slope gradient. Catena 38: 211-222.

Freebairn DM, Wockner GH. 1986. A study of soil erosion on vertisols of the eastern Darling Downs, Queensland. I. The effect of surface conditions on soil movement within contour bay catchments. Australian Journal of Soil Research 24, 135-158.

Gabriels D, 1999. The effect of slope length on the amount and size distribution of eroded silt load soils: short slope laboratory experiments on interrill erosion. Geomorphology 28: 169-172. 
Gómez JA, Nearing MA. 2005. Runoff and sediment losses from rough and smooth soil surfaces in a laboratory experiment. Catena 59: 253-266.

Gómez JA, Darboux F, Nearing MA. 2003. Development and evolution of rill networks under simulated rainfall. Water Resources Research 39(6): 1148 DOI: $10.1029 / 2002$ WR001437.

Govers G, Giménez R, Van Oost K. 2007. Rill erosion: exploring the relationship between experiments, modelling and field observations. Earth-Science Reviews 84: 87-102.

Jin CX. 1995. A theoretical study on critical erosion slope gradient. Journal of Geographica Sinica 50: 234-239.

Jordán A, Zavala LM, Gil J. 2010. Effects of mulching on soil physical properties and runoff under semi-arid conditions in southern Spain. Catena 81: 77-85.

Kim KH, Miller WP. 1996. Effect of rainfall electrolyte concentration and slope infiltration and erosion. Soil Technology 9: 173-185.

Kinnell PIA. 2000. The effect of slope length on sediment concentrations associated with side-slope erosion. Soil Science Society and American Journal 64: 1004-1008.

Kinnell PIA. 2005. Raindrop impact induced erosion processes and prediction: a review. Hydrological Processes 19: 2815-2844.

Knapen A, Poesen J, De Baets S. 2007a. Seasonal variations in soil erosion resistance during concentrated flow for a loess-derived soil under two contrasting tillage practices. Soil and Tillage Research 94 $425-440$.

Knapen A, Poesen J, Govers G, Gyssels G, Nachtergaele J. 2007b. Resistance of soils to concentrated flow erosion: a review. EarthScience Reviews 80: 75-109.

Léonard J, Ancelin O, Ludwig B, Richard G. 2006. Analysis of the dynamics of soil infiltrability of agricultural soils from continuous rainfall-runoff measurements on small plots. Journal of Hydrology 326: $122-134$.

Lei TW, Zhang QW, Yao CM, Yan LJ, Liu H, Yang C. 2005. Theoretical analysis of estimation error of soil erodibility for rill erosion in WEPP model. Transactions of the CSAE 21: 9-12.

Liu QQ, Chen L, Li JC. 2001. Influences of slope gradient on soil erosion. Applied Mathematics and Mechanics 22: 449-457.

Loch RJ, Donnollan TE. 1983. Field rainfall simulator studies on two clay soils of the Darling Downs, Queensland. I. The effects of plot length and tillage orientation on erosion processes and runoff and erosion rates. Australian Journal of Soil Research 21: 33-46.

Loch RJ. 1996. Using rill/inter comparisons to infer likely responses of erosion to slope length: implications for land management. Australian Journal of Soil Research 34: 489-502.

Luk SH, Cai Q, Wang GP. 1993. Effects of surface crusting and slope gradient on soil and water losses in the hilly loess region, North China. Catena Supplement 24: 29-45.

Mancilla GA, Chen S, McCool DK. 2005. Rill density prediction and flow velocity distributions on agricultural areas in the Pacific Northwest. Soil and Tillage Research 84: 54-66.

Mermut AR, Luk SH, Römkens MJM, Poesen JWA. 1995. Micromorphological and mineralogical components of surface sealing in loess soils from different geographic regions. Geoderma 66: 71-84.

Mermut AR, Luk SH, Römkens MJM, Poesen JWA. 1997. Soil loss by splash and wash during rainfall from two loess soils. Geoderma $\mathbf{7 5}$ : 203-214.

Murphy BW, Flewin TC. 1993. Rill erosion on a structurally degraded sand loam surface soil. Australian Journal of Soil Research 31: 419-436.
Neave M, Rayburg S. 2007. A field investigation into the effects of progressive rainfall-induced soil seal and crust development on runoff and erosion rates: the impact of surface cover. Geomorphology 87: 378-390.

Poesen J. 1984. The influence of slope angle on infiltration rate and Hortonian overland flow volume. Zeitschrift für Geomorphologie Supplement 49: 117-131.

Ran Q, Su D, Li P, He Z. 2012 Experimental study of the impact of rainfall characteristics on runoff generation and soil erosion. Journal of Hydrology 424: 99-111.

Rejman J, Brodowski R. 2005. Rill characteristics and sediment transport as a function of slope length during a storm event on loess soil. Earth Surface Processes and Landforms 30: 213-239.

Renard KG, Me Cool DK, Cooley KR, Foster GR, Istok JD, Mutchler CK. 1997. Rainfall-runoff erosivity factor. In Predicting Soil Erosion by Water: A Guide to Conservation Planning with the Revised Universal Soil Loss Equation (RUSLE). Agriculture Handbook No. 703. Chapter 2, U.S. Department of Agriculture: Washington, 19-64.

Robichaud PR, Wagenbrenner JW, Brown RE. 2010. Rill erosion in natural and disturbed forest: 1. Measurements. Water Resources Research 46, doi:10.1029/2009WR008314.

Savat J, De Ploey J. 1998. Sheetwash and rill development by surface flow. In Badland Geomorphology and Piping, Eryan RB, Yair A (eds). Geo Books: Norwich, 113-126.

Shao XJ, Wang H, Hu H. 2005. Experimental and modelling approach to the study of the critical slope for the initiation of rill flow erosion. Water Resources Research 41, W12405 DOI: 10.1029/2005WR003991.

Shi ZH, Fang NF, Wu FZ, Wang L, Yue BJ, Wu GL. 2012. Soil erosion processes and sediment sorting associated with transport mechanisms on steep slopes. Journal of Hydrology 454-455: 123-130.

Shi ZH, Yan FL, Li L, Li ZX, Cai CF. 2010. Interrill erosion from disturbed and undisturbed samples in relation to topsoil aggregate stability in red soils from subtropical China. Catena 81: 240-248.

Shi ZH, Yue BJ, Wang L, Fang NF, Wang D, Wu FZ. 2013. Effects of mulch cover rate on interrill erosion processes and the size selectivity of eroded sediment on steep slopes. Soil Science Society of America Journal 77: 257-267.

Singer MJ, Bissonnais YL. 1998. Importance of surface sealing in the erosion of some soils from a Mediterranean climate. Geomorphology 24: $79-85$.

Singer MJ, Shainberg I. 2004. Mineral soil surface crusts and wind and water erosion. Earth Surface Processes and Landforms 29: 1065-1075.

Sirjacobs D, Shainberg I, Rapp I, Levy GJ. 2000. Polyacrylamide, sediment, and interrupted flow effects on rill erosion and intake rate. Soil Science Society of American Journal 64: 1487-1495.

Wainwright J. 1996. Infiltration, runoff and erosion characteristics of agricultural land in extreme storms, SE France. Catena 26: 27-47.

Wirtz S, Seeger M, Ries JB. 2012. Field experiments for understanding and quantification of rill erosion processes. Catena 91: 21-34.

Woodward DE. 1999. Method to predict cropland ephemeral gully erosion. Catena 37: 393-399.

Zartl AS, Klik A, Huang C. 2001. Soil detachment and transport processes from interrill and rill areas. Physical, Chemical and Earth Sciences 26: 25-26.

Zaslavsky D, Sinai G. 1981. Surface hydrology: IV. Flow in sloping, layered soil. Journal of the Hydraulics Division 107: 53-64.

Zheng FL, Tang KL, Zhou PH. 1989. Study on factors affecting rill erosion on cultivated slope land. Acta Pedologica Sinica 26: 109-116. 